\title{
Symbiotic Harms of Imprisonment and the Effect on Children's Right to Family Life
}

\section{Comparing the Impact of COVID-19 Prison Visiting Restrictions in the} UK and Australia

\author{
Shona Minson \\ British Academy Post-Doctoral Fellow, Centre for Criminology, \\ University of Oxford, Oxford, UK \\ shona.minson@crim.ox.ac.uk \\ Catherine Flynn \\ Faculty of Medicine, Nursing and Health Sciences, Monash \\ University,Melbourne, Australia \\ catherine.flynn@monash.edu
}

\begin{abstract}
Measures taken by governments to address COVID-19 in prisons, have impacted significantly on the lives and rights of children. There has been consequential interference with children's rights to family life and to contact with a parent from whom they have been separated. Since the onset of the pandemic, prisoners in many jurisdictions have lived under restricted regimes with almost universal bans on family visits. Children have not had face-to-face contact with their imprisoned parents, and alternate forms of contact have not always been available to them. Using survey and interview data collected during lockdowns in the UK and Australia, we consider the implications of the interference with the rights of children with an imprisoned parent. Focusing on their relationships, health and wellbeing and using the concept of symbiotic harms, we note how children's experiences of the cessation of contact interacted with parents' and caregivers' experiences, amplifying the harms to children.
\end{abstract}




\section{Keywords}

parental imprisonment - right to family life - visiting contact - prison - symbiotic harms - prisoners' families

\section{Introduction}

Under Article 9(3) of the United Nations Convention on the Child, 1989 ("UNCRC"), ratified by Australia and the UK, children have a right to maintain personal relations and direct contact with both parents unless it is contrary to the child's best interests. Further, under Article 8 of the European Convention on Human Rights as incorporated into UK domestic law by virtue of the Human Rights Act 1998, a child has a right to respect for their family life. When a parent is imprisoned without their child, there is an obvious interference with these rights. Consideration of this within the courts of England and Wales has led to case law $(R$ (on the application of $P$ and $Q) v$. Secretary of State for the Home Department [2001]) which established:

The criminal sentencing of a parent engages the Article 8 right to respect for family life of both the parent and the child. Any interference by the state with this right must be in response to a pressing social need, in pursuit of a legitimate aim, and in proportion to that aim. The more serious the intervention the more compelling the justification must be. (IBID.: PARAS. 78 AND 87 ).

Australia has no overarching federal human rights law, and only two jurisdictions, the Australian Capital Territory (2004) and Queensland (2019), have enacted a Human Rights Act. While both ensure an adult's rights in criminal proceedings and to humane treatment in custody, as well as children's right to protection, these two responsibilities are seen and treated independently. In Victoria, while the Charter for Human Rights and Responsibilities Act (2006) establishes the right not to have one's family 'arbitrarily interfered with' (Article 13(10)), and to the protection of families as 'a fundamental group unit of society' (Article 17(11)), these provisions are not enforceable. Across Australia, the impact of a sentence on children or other family is absent in legislation, and children are not afforded any specific consideration or protection.

However, when a parent is imprisoned in either jurisdiction, although a child's right to family life and contact is necessarily and inevitably curtailed, it is not usually removed in its entirety. There is assumed to be the possibility 
of upholding a limited right to family life and contact for the child during the period of the imprisonment, primarily through visits at the prison between the child and the imprisoned parent. Of course, not all children want to see their parent and many are unable to visit. Distance is a practical barrier as people are detained far from their home (Clark and Duwe, 2016; Trotter et al., 2015) and the cost (Scharff Smith and Jakobsen, 2014) compounds the financial pressures of imprisonment (Flynn, 2014). Children rely on adults to facilitate contact, and it is reported that around one-half of imprisoned parents receive no visits (Glaze and Maruschak, 2008), as complex relationships affect carers' willingness to visit (Tasca, 2018) or parents' willingness to receive visits (Bartlett and Eriksson, 2018). However, the fact that there is provision for visits to take place means that the child's right to family life and their Article 9(3) right to contact are recognised. It is therefore noteworthy that measures taken within prisons in Australia and the UK to manage the COVID-19 pandemic have severely encroached on children's rights to family life and contact, with consequential adverse impacts on children's relationships, health and wellbeing. We begin by outlining the restrictions on prison visits as a result of the pandemic.

\section{$2 \quad$ Background}

\subsection{COVID-19 and Prisons}

The World Health Organisation (wHO) declared CoviD-19 a pandemic on 11 March 2020. Soon after it provided guidance on preventing and responding to COVID-19 in prisons (WHO, 2020). These were deemed to be sites of high risk, due to overcrowding and difficulties in instigating effective preventative measures, including hygiene, physical distancing and infection control. Prisoners have increased vulnerability to COVID-19 (Prison Reform International [PRI], 2020), with compromised health, chronic health conditions, increased rates of mental illness and substance dependence. Many prisons began to limit contact through visiting restrictions or bans; some concurrently provided increased opportunities for other forms of contact, such as phone calls (PRI, 2020). Prison lockdowns were widespread in 2020 continuing in some countries into 2021.

Due to the recency of events and the "invisible" nature of children affected by parental imprisonment (Knudsen, 2018), our understanding of both the short and longer-term impact of these restrictions on children and families remains poor, particularly where such arrangements are both enduring and indefinite. We do know, however, that the rapid cessation of in-person contact meant that little planning took place to prepare children to say goodbye to 
their parent, or for relevant supports or technology to be put in place, either within the prison or for families on the outside. Information on children's experiences of reduced contact has come from media reports, advocacy organisations or prisoners' families on social media (Children Heard \& Seen, 2020: CHRIPA, 202O: Moore, 2020; Williams, 2021), but this paper reflects on data from two separate empirical studies which took place across three jurisdictions during lockdowns in 2020. The first was conducted in England and Wales and in Scotland, which exist as two separate legal jurisdictions but which will be referred to as 'UK', whilst the second was conducted in Australia. Data was collected between April and August 2020, when both settings experienced varied levels of lockdown. In-person prison visits were cancelled in the UK around 13 March 2020. Some prisons reopened for in-person visits in June or July 2020, but many remained closed due to regional lockdowns. National lockdowns were re-imposed during November and December, and a further nationwide lockdown, which remains in place at the time of writing, began in Wales on 19 December 2020 and England and Scotland on 4 January 2021. At the time of writing no in-person prison visits are taking place. In-person visits in all Australian prisons stopped in March 2020. Across Australia, prisons are administered by individual states and territories, and therefore the resumption of visits varied considerably. Face-to-face visits resumed as early as May 2020 in the Northern Territory, and at the time of writing had resumed across most Australian jurisdictions, although on 4 February 2021 they were suspended indefinitely in Victoria.

\subsection{The Importance of Visits between a Child and their Imprisoned Parents}

For children who are able to see their parent the visiting experience can still be difficult. Surveillance, security and a resultant lack of privacy create an intimidating environment (Scharff Smith and Jakobsen 2014) which may frighten children (Nesmith and Ruhland, 2008). Despite these shortcomings it is well established that visiting has a range of benefits for children and for their relationship with the imprisoned parent, both in the short and longer term (Arditti, 2012; Tasca et al. 2016; Cranmer et al. 2017). Visits have an impact on family connectedness and can affect the parents' ability to remain involved with their child during and after imprisonment (Arditti et al., 2005). In their review of research on child/parent prison visitation, Cranmer et al. found:

research indicates that parent-child visits are most beneficial when they allow for physical contact, are offered in a child-friendly setting, are part of a family strengthening program, and provide proper emotional preparation and debriefing before and after. Experts also find that physical 
contact and privacy during visits benefit both children and parents and help them cope emotionally and reconnect with each other (CRANMER ET AL., 2017:7).

The cessation of children's in-person prison visits with an imprisoned parent in Australia and the UK due to the COVID-19 pandemic, not only interferes with their rights to family life and contact but may also have negative impacts on children's lives and family structures. While there is limited evidence on how children fare when contact is not maintained, because children's lives are intricately connected with their parents' and are mutually influencing, it can be reasonably hypothesised that these children experience a range of symbiotic harms (Condry and Minson, 2020). A sustained lack of physical contact with a primary adult will have consequences for bonding, attachment and guidance on behaviour (Navaez et al., 2019), and face-to-face contact enables mitigation of the harms of physical separation. As well as missing out on the immediate benefits of seeing each other, a lack of contact makes it more difficult for a parent to remain engaged with and committed to their parenting role and identity (Bartlett and Eriksson, 2018). Parents who are able to prioritise their family over a criminal identity (Berg and Huebner, 2011) are likely to be able to form more stable family structures on release.

\section{3}

\section{Methods}

While the aim of each study varied, pooling and comparing the results allows for the findings and conclusions to be strengthened and validated (Tashakkori \& Teddlie, 2010). Drawing on different data sets and methods, bringing a mixed methods approach allows complex social phenomena to be investigated in multiple ways, from multiple viewpoints (Bazeley, 2018).

Data were gathered from families via anonymous online surveys, in the UK from 20 April to 13 June 2020, and in Australia from 17 June to 17 August 2020. In the UK the survey was distributed via social media, including the social media channels of organisations supporting prisoners' families. It asked for responses from caregivers looking after children with a parent in prison. In Australia the survey was distributed via SHINE for Kids ${ }^{1}$ (who commissioned the study), not for profit organisations and a range of social media platforms. The survey asked for responses from an adult caring for children with a family member

1 SHINE for Kids is an Australian not-for-profit organisation, which provides services to support children, young people and families with a relative in the justice system. They provide services across four states/territories https://shineforkids.org.au/. 


\begin{tabular}{llll} 
Setting & Participants & Sample & Methods \\
\hline $\begin{array}{l}\text { England, Wales, } \\
\text { Scotland }\end{array}$ & Adult carers & 36 adults, caring for 71 children & $\begin{array}{l}\text { Survey } \\
\text { Interview }\end{array}$ \\
Australia & Adult carers & 84 adults caring for 184 children & Survey \\
\hline
\end{tabular}

in prison. Details about study participants, including location and methods of data collection are noted in Table 1. 85 per cent of the children represented in the 84 responses from carers, had a parent in prison. In both studies a survey was used to improve understanding of the needs and experiences of children with a family member in prison with regard to the impact of reduced contact during CoviD-19. When engaging in research about children it is preferable to engage directly with children, even when such children are viewed as "vulnerable" (UNCRC, 1989; Mahon et al., 1996; UNCRC, 2009: Garcia-Quiroga and Agoglia, 2020), not just asking them about their experiences but also assisting children to form their views (Lundy and McEvoy, 2012). However, the circumstances of the pandemic meant that for ethical reasons the decision was taken to use indirect means to find out about children's experiences by seeking wide and descriptive data from children's carers. The surveys gathered descriptive data on the type and frequency of contact pre and during CoviD-19; the challenges experienced in maintaining contact; factors affecting visiting and other forms of contact; perceptions of the availability and quality of contact between children and the imprisoned family member; the perceived effects on children; carers' self-reported coping, their observations on how both the children and the imprisoned family member were coping; as well as suggestions for improvements. The UK study gathered data from surveys completed by 36 carers looking after 71 children, and 6 carers looking after 19 children also chose to participate in online research interviews. Whilst the Australian survey gathered primarily quantitative data, for the purposes of this article we focus on the qualitative data gathered via a small number of open-ended questions, which provide participant descriptions of their experiences of maintaining contact with a parent during COVID-19 restrictions.

Findings

\subsection{Demographics}

In the UK all the children represented had a parent in prison [n=71]. Five per cent of children were less than 12 months old, 24 per cent were aged between 
one and five years, 42 per cent were aged between six and 11 years, and 29 per cent were aged $12-18$ years. For eight of the 71 children their mother was in prison, for $5^{8}$ children their father was in prison, and five children had both parents in prison. Of the caregiver respondents, 78 per cent were the children's mother, one per cent were the stepmother, and 21 per cent were the children's grandmother. For all it was their partner, spouse or child who was in prison. In 53 per cent of households the total income was less than $£_{15}$,ooo. In 81 per cent of households the total income was less than $£ 25$,ooo. The average household disposable income in the UK in 2020 was $£_{30}, 800$ (Office for National Statistics, 2020).

In Australia, as noted above, around 85 per cent of the children had a parent in prison. 12 per cent were aged under two years, 19 per cent were aged two four years, $3^{2}$ per cent were aged five - nine years, while 37 per cent were ten 17 years old. The majority of caregivers completing the survey were women (99 per cent, $N=83$ ) and most ( 83 per cent) reported being the mother of the child/ ren they were caring for, while the person in prison was the child/ren's other parent. Eight per cent were grandparent carers. 83 of respondents identified as non-Indigenous. 16.7 per cent $(n=14)$ of principal children were described as needing regular help with daily activities due to disability or chronic illness. This is considerably higher than in the community population, where 7.4 per cent of children aged $0-14$ years have some type of disability (Australian Institute of Health and Welfare [AIHW], 2020).

\subsection{Contact between the Imprisoned Parent and Child Pre-Pandemic}

Prior to the cessation of visits, most children in the UK study had regular in-person contact with their imprisoned parent. 59 per cent of children $[\mathrm{n}=71]$ saw their parent at least weekly in addition to daily phone calls. 13 per cent saw their parent fortnightly, and 7 per cent had monthly visits. 15 per cent of the children spent time with their parents at home rather than at the prison as the parents had ROTL (release on temporary licence) or CRL (child resettlement leave). In most instances this was for five days each month and included overnight stays. Only four per cent of children had no contact with their parent prior to the pandemic. In some cases, this was the child's choice, whilst in others it was because a carer did not want to bring them to the prison.

In Australia, most of the imprisoned family members $(n=75)$ were incarcerated prior to the CoviD-19 suspension of face-to-face visits. Similar patterns of contact to the UK are evident: 45 per cent of respondents $(n=29)$ described weekly in-person contact, with 22 per cent having fortnightly visits, and uper cent monthly. Just less than five per cent reported no regular visiting prior to the pandemic. Contact was also maintained via phone calls ( 96 per cent) and 
letters (59 per cent). Although visiting has been described in much literature (Flynn, 2014) as difficult, most respondents did not describe problems with maintaining contact pre-COVID and 68 per cent of respondents described the availability of contact as good or very good.

Across both studies, pre-lockdown contact was reported to be positive for the children. In Australia two-thirds of carers rated the quality of contact as good or very good. In the UK, respondents described even young children who had only known their imprisoned parent in prison, developing a relationship with their imprisoned parent. This suggests that despite the challenges of prison visits, these arrangements facilitated family life, meaningful interaction, and interdependence, enabling children and parents to manage and mitigate the symbiotic harms of separation.

It was fantastic ... She loves her Dad and only sees him once a week. As soon as she sees him her face lights up and she's so happy. He's a fantastic Dad. (UK)

She'll run up to him to be picked up, hugs and kisses. Yeah, she absolutely adores him. Thinks the world of him. (UK)

\subsection{Contact between the Imprisoned Parent and Child During Lockdown}

At the time of the UK study no participant families had been able to access video calls or face-to-face visits since 13 March 2020. Most had telephone calls, although those were shorter and less frequent than pre-pandemic. Prisoners without in-cell telephony spent limited time outside their cells and therefore had less time to use shared telephones. Video calls were not available in all prisons until January 2021 (Ministry of Justice, 2021).

In Australia while the quantitative data indicated that the vast majority of families had some form of contact during restrictions (phone calls [9iper cent]; video conferencing [75 per cent]), around 6o per cent described problems maintaining this contact. The problems were typically attributed to prison facilities or functioning, notably prison lockdowns ( $\mathrm{n}=34 ; 68$ per cent), shortened time for visits ( $\mathrm{n}=33$; 66 per cent), and poor or no access to video visits at the prison ( $\mathrm{n}=25 ; 50$ per cent). One-half of respondents who indicated problems, however, describe the children as not wanting to participate in video visits $(\mathrm{n}=25)$.

It's also hard for young children to maintain a conversation on an iPad especially when it freezes and her Dad can't hear her. (AUSTRALIA) 
A small number of respondents $(n=23)$ described some positive effects of the changed visiting regime. These were the reduced time/cost involved: not needing to travel to the prison and not needing to take the children into a prison environment. Some identified that video calls were more private and less distracting for children than face-to-face contact in a visits centre, "bringing some normality", with children showing their pets and activities, and the imprisoned parent participating in things like children's bedtime routines.

The kids have been able to share more with their father such as reading stories together, showing him their awards and artwork. (AUSTRALIA)

However, even children who had video or phone calls with their parent experienced negative impacts from the lack of face-to-face contact, and in the next sections we consider the impacts on children's relationships, health and wellbeing caused by the cessation of visits with their imprisoned parents.

\subsection{Relational Impacts on Children}

The sudden and unanticipated removal of all face-to-face contact with their parent had consequences for children's ongoing relationships with the parent in prison and with the person caring for the child at home, as the relationships between child, parent and caregiver, are mutually influential and mutually reinforcing.

4.4.1 The Child's Relationship with the Imprisoned Parent

Many children found it very difficult to cope without any physical relationship with their imprisoned parent.

She needs the weekly physical contact with her Dad to maintain some form of normality for her. (AUSTRALIA)

They can't touch, cuddle or have fun with their dad. They understand it's because of the virus to keep him safe but they want to be able to have more time with their dad. (AUSTRALIA)

They are missing physical contact with their Dad. (UK)

My child recently lost his first tooth, he wanted to show his dad the gap in his mouth and cried knowing he can't so I said I would send a photo to his dad and he said no mummy I want him to see it when I sit on his knee then he can really see. (UK) 
Although telephone calls were available, some children couldn't access them. Carers expressed concern for pre-verbal or non-verbal children who showed little recognition of their parent's voice and were unable to communicate with their parent due to their lack of speech.

Unfortunately for my seven-year-old he can't communicate on a phone so now he has no contact whatsoever with dad. (UK)

My son has never seen his daddy as he was asleep both times he visited and that was at two weeks old. He is now three months. (UK)

My granddaughter needs her dad to hug. Video visits aren't the same for a four-year-old. (AUSTRALIA)

Daily phone calls occur but [it's] hard to communicate with a child who cannot talk properly yet. (AUSTRALIA)

As a consequence of the restrictions within the prisons, parents' calls to their children were shorter and less frequent (due in part to the demand for shared telephones). Video calls, when available, were for a short duration. Children expressed anger and emotional confusion towards their imprisoned parent for not wanting to see them and some children no longer wanted to talk to their parent on the phone.

He worries his Dad will forget him. (UK)

My kids are feeling very detached from their Dad and don't even want to take his calls. (AUSTRALIA)

Face-to-face visits were five hours long and [audio-visual link] visits are a measly 25 mins. (AUSTRALIA)

[They] think he doesn't care about them because he can only ring for five minutes per day. (UK)

Sometimes if she's busy doing something she's not really that interested in speaking to him on the phone, and sometimes she'll go on the phone and chatter away, and tell him everything she's been up to. (UK) 
Caregivers described the relationship between children and imprisoned parents as 'absolutely damaged', as parents in prison found it hard to have only telephone or video contact with their children, and in the worst cases this led to a complete breakdown in contact:

Their Dad doesn't know how to communicate in this way. He's awkward and then the kids don't want to visit with him. (AUSTRALIA)

Six days ago he cut off contact because it's too hard for him. (UK)

My son is only 11 months old and bonding with his father is crucial for him to learn who he is. It affects my partner's mental health when he doesn't have a bond with his son who is his only child and was born while he was imprisoned. Having gone months without visits has broken the bond which took some time to build up. (AUSTRALIA)

He's really gutted. He hears me on the phone saying, "come on talk to your Dad" and he hears her saying, "No". (UK)

The children start to cry on the phone and obviously then that upsets Dad and he blames himself for being in there. And obviously it affects Dad as well because he knows how serious this virus is. He's in there and can't do nothing to help. Which is a major stress and worry for him on his part as well. (UK)

The suspension of face-to-face visits removed physical touch, a primary means of interaction and communication for children. The alternatives offered, phone or video, may be less suitable for young or disabled children; we know that children of prisoners tend to be young (e.g. see Maruschak, Bronson and Alper, 2021), and have a range of other challenges including, 'homelessness, stigmatisation, criminal behaviour, poor physical and mental health, behavioural issues, substance misuse, and premature departure from home' (McCrickard and Flynn, 2015: 40). When compared to face-to-face visits, parents in prison are limited to very short periods of time for phone or video calls, and so their strategies for connection, and the creation and development of their relationships with their children in ways that manage the harms of separation, were disrupted. The changed circumstances are causing the parents difficulties, making them less available to their children, and reducing their opportunities 
and ways to manage the children's distress. This in turn affects the child's interactions with the caregiver at home.

4.4.2 The Child's Relationship with the Caregiver

The caregiver/child relationship can act as a protective factor for children with an imprisoned parent, but stressors to the caregiver can diminish the benefits of the relationship to the child (Dallaire, 2007; Mackintosh et al., 2006). Both studies found that caregivers were impacted negatively both by the cessation of their own contact with the imprisoned person (in many cases their partner or child), and by witnessing and managing the child's response to the cessation of face-to-face contact, often as a sole parent. A high proportion of UK caregivers reported a worsening of their pre-existing mental illness or new diagnosis of mental illness since prison lockdown was imposed. This in turn affected their relationship with the children.

It's been very hard not being able to see him and my existing anxiety and depression has worsened. (UK)

They blame me for not seeing their Dad. (UK)

It seems to me that he is dead. I have had many panic attacks since our contact stopped. I feel sorry for my child because I am struggling myself. (UK)

The support networks [are] not as easily accessible during CoviD. (AUSTralia)

I can't talk to my husband. phone calls are 5 minutes and AVL calls are 25 minutes. with three kids vying for the attention time goes very fast. I haven't been able to feel connected to him, I haven't been able to have a hug to feel better. My mental health has been at an all-time low. (AUSTRALIA)

The relational nature of the harms experienced by prisoner's families means that, in addition to their own distress, the distress of both the child and the imprisoned parent are felt by the carer. They, without the support they previously received from the imprisoned person and from services they engaged with when visiting or in the community, feel overwhelmed, and this in turn impacts upon the child. 
In the next section we examine how the damage to relationships caused by the cessation of prison visits, compounded by the mutuality of family members' experiences, leads to harms to children's health and wellbeing.

\subsection{Health and Wellbeing Impacts on Children}

The lack of advance notice of the cessation of in-person contact, the uncertainty regarding its duration, the lack of support to children and families to enable alternative modes of contact, the restricted indirect contact available, and the consequent difficulties with the parent/child and caregiver/child relationships, resulted in negative emotions and behaviours in most children.

\subsubsection{Anxiety about the Imprisoned Parent}

Children experienced increased anxiety about their parents' wellbeing in prison and the likelihood of seeing their parent again. They asked questions of their caregivers such as: 'Will my Dad die?'; 'Do they have enough food?'; 'Why can't they facetime?'; 'Do they still love me?'; 'Did I do something wrong?'; 'When will we see each other?'. Their anxiety manifested in a variety of ways including crying, sleeplessness, nightmares and attachment issues.

He has had nightmares about his Dad catching "the corona" in prison, he wakes up in tears and shaking. I had to move him into my bed. (UK)

She has been worried that Daddy won't be able to get food because the shops have run out of certain things and has felt sad for daddy being on his own. (UK)

They're devastated and worried, extremely worried. They're scared of the virus in prisons. (UK)

My son has asked me if his Dad is going to die. (UK)

My children are anxious about their father's wellbeing. (AUSTRALIA)

\subsubsection{Behavioural Changes}

Changes to behaviour reported by caregivers included anger, aggression, becoming quiet and withdrawn, being verbally and physically abusive, destroying property, bedwetting, soiling, and becoming clingy with their caregiver. Some children found it difficult to eat and it was reported that a sevenyear-old whose disability precluded him from using the telephone had lost a stone in weight since contact stopped. While wider aspects of lockdown such 
as closure of schools, isolation from friends, restrictions on movements, likely compounded these changes in children's behaviour, it is important to note that carers ascribed these to separation from the imprisoned parent.

My children are both showing huge changes in behaviour, which is impacting their sleep, eating and much more. (AUSTRALIA)

[He's] upset that he cannot see his mum. He is withdrawn and not very talkative. (UK)

My child is very distressed, it's affecting his learning, behaviour and emotional wellbeing. (AUSTRALIA)

When she has a breakdown over her Dad she does get physical with me. (UK)

\subsubsection{Mental Health}

Children's mental health was affected and this manifested in the development of eating disorders, self-harm, depression and anxiety.

My 12 year old has just started to make herself sick after eating and when you ask her why she's doing it she says, 'I miss my dad and nobody understands'. (UK)

My child has self-harmed, been very anxious, had nightmares about something bad happening to her Dad and constantly worrying about him (UK)

Huge effect on overall mental health. Children are anxious, depressed, don't want to go to school, are angry at the parent and blaming them and myself. (AUSTRALIA)

The effect has been huge, and has resulted in nightmares, bad sleeping patterns and depression. (AUSTRALIA)

Increased anxiety and separation problems with my two autistic children ... My oldest thinks daddy is gone for good now and cries daily about not being able to see him. (AUSTRALIA)

My seven-year old suffers from severe anxiety stemmed from father's incarceration which has worsened since suspended visits. (AUSTRALIA) 
The concept of "symbiotic harms" (Condry and Minson, 2020) is a useful framework to understand how the interference with children's rights, experienced through a lack of contact with their imprisoned parent during prison lockdown, has impacted children. Symbiotic harms have been defined as 'negative effects that flow both ways through the interdependence of intimate associations such as kin relationships' (ibid, 1:2020). The concept was developed to allow for the wider effects of punishment to be recognised and discussed in a way that engaged with their complexity. Condry and Minson argue that symbiotic harms experienced by prisoners' families are relational, mutual, non-linear, agentic and heterogeneous. When exploring the harms suffered by children due to the cessation of face-to-face contact with their parent during COVID-19 prison lockdown, the mutual and relational aspect of the harms are apparent as the child's, parent's and caregiver's experience interact, amplifying the harms. The child finds the lack of physical contact difficult and doesn't like to speak to the parent on the telephone. The parent finds telephone communication very awkward and is upset that the children do not want to talk with them, so reduces contact. The child is harmed by the reduction in the contact, and so it continues. The same is true of the interaction between the caregiver's experience and child's experience. Both struggle with the changes wrought by the situation and their distress impacts the other.

Symbiotic harms recognise that families often manage such crises by employing strategies to resist or to survive. One of the most difficult aspects of the COVID-19 prison lockdown has been the removal of this aspect of self-determination from prisoners' families. In pre-pandemic times, families had agency to make the best of the situation they found themselves in, for example spending hours travelling to visits at prisons, or ensuring that children were available for daily phone calls (Christian, 2005; Minson, 2019). During the pandemic, families cannot restore face-to-face contact, and the sporadic nature of indirect contact has removed their ability to make plans.

It's the frustration of not being able to do anything about it because it's out of our hands. I like to be in control of things in my life. I like to be able to do something because there's always a solution to a situation and I always try and find that solution but there's nothing It's like drowning. There's just nothing to grab on to. (UK)

The non-linear aspect of the harms means that the parent's release from prison is unlikely to bring an end to the disruption of the child's right to family life. In pre-pandemic times re-integration could be difficult due to the diminution 
of relationship between parent and child (Richie, 2001; Loucks, 2004, Garcia, 2016) but the total lack of physical contact for periods during the pandemic is likely to make re-establishing relationship even more difficult. Caregivers expressed concerns about the challenge for the parent, who may have effectively lived in solitary confinement for an extended time, as they readjust to the intensity of life with children.

Biggest concern is how lasting damage will be and whether my daughter and [her] son will ever regain a strong healthy bond as they had. Sadly I don't think it can ever go back to how it was. Her son is now attached to me as he's had to be. I think my daughter will struggle resuming being a mother especially when her son will not be attached to her how he was. I expect the ramifications of this separation to be huge and long lasting for both (UK)

Parental imprisonment is known to have life-long impacts on children (Wakefield \& Wildeman, 2014; Mears \& Siennick, 2016; van de Weijer, Smallbone, \& Bouwman, 2018), and caregivers expressed concerns about the likely long-lasting impacts on children of the loss of contact with their parents:

Due to his current anxiety around the whole imprisonment it's hard to determine the long-term effect this may have on him (UK)

When there were no visits at all, it has had long-lasting attachment issues on the child and she has ongoing trust issues and ongoing nightmares. (AUSTralia)

In both Australia and the UK children whose parent was in prison during the prison lockdowns of COVID-19 were unable to fully exercise their right under Article 9(3) UNCRC (1989) to maintain direct contact with their parent. In the short term, the data snapshot suggests lack of contact has had serious implications for children's relationships, health and wellbeing. It is too early to know the longer-term effects, but it is likely that this period without contact will increase the difficulties of family re-integration after imprisonment. The data indicate that families who've experienced imprisonment during the pandemic lockdowns may be more fragile and less prepared or resilient than they might 
otherwise have been. The ruptured relationships and connection, the likely trauma of extended periods of confinement inside prison, and community lockdown outside prison, and each individual's own experiences of increased anxiety and mental stress, will make re-integration challenging.

Going forward it is important to be mindful of the call for video technology to be used when face-to-face visits are not allowed. Children in both Australia and the UK experienced similar negative impacts from the loss of face-to-face contact even though in the Australian study 75 per cent of children were having video calls with their imprisoned parent. From this finding we would suggest that although video calls can augment face-to-face contact and may be particularly useful for families for whom travel time/distance/cost are barriers, they should not replace in-person contact.

Both studies had limitations due to the relatively small numbers of participants, and lack of diversity of respondents, as recruitment of participants during pandemic was reliant on digital access which many families of prisoners do not have. Although different demographic data were collected in the UK and Australia, it is notable that the participants came disproportionately from low income (UK), and Indigenous groups (Australia). This is consistent with a long-established body of global research which evidences the intersectionality of poverty, race and incarceration (Western and Pettit, 2010; Duque \& McKnight, 2019; Leigh, 2020).

These two studies combined offer initial empirical evidence of the adverse consequences to children who had a parent imprisoned during the CoviD-19 visiting restrictions, and the likely implications for family reunification. Overriding a child's right to contact with their imprisoned parent, even when seemingly justified on public health grounds, has serious implications not just for the child but also for their adult family members and for their future family stability.

\section{References}

Arditti, J., "Child Trauma within the context of parental incarceration: A Family Process Perspective", Journal of Family Theory and Review (2012) 4(3): 181-219.

Arditti, J. A., Smock, S. A. and Parkman, T. S., "It's been hard to be a father': a qualitative exploration of incarcerated fatherhood", Fathering 2005 (3(3), 267-288.

Australian Institute of Health and Welfare, Australia's Children, 2020. Accessed 3 October 2020: https://www.aihw.gov.au/reports/children-youth/australias-children/ contents/health/children-disabilities. 
Bartlett, T. and Eriksson, A., "How fathers construct and perform fathering in a liminal prison space", Punishment and Society, 2018 (21(3), 275-294.

Bazeley, P., "Mixed Methods in my Bones: Transcending the Qualitative-Quantitative Divide", International Journal of multiple research approaches 2018 (10(1)), 334-341. Doi.org/10.29034/ijmra.vionı22.

Berg, M. and Huebner, B., "Reentry and the ties that bind: An examination of social ties, employment, and recidivism", Justice Quarterly 2011 (28(2), 382-410.

Children Heard and Seen, Life in Lockdown: How prison lockdown impacted the children and families of prisoners (2020): https://www.childrenheardandseen.co.uk/ wp-content/uploads/2020/10/Life-In-Lockdown-Report-2020.pdf.

Christian, J., "Riding the Bus: Barriers to Prison Visitation and Family Management Strategies", Journal of Contemporary Criminal Justice 2005 (21(1)), 31-48.

Clark, V. and Duwe, G., "Distance matters: Examining the factors that impact prisoner visitation in Minnesota”, Criminal Justice and Behavior 2016 (44(2), 184-204.

Coalition for the Human Rights of Imprisoned People in Australia (CHRIPA), "Suspending family visits will not prevent COVID-19", 23 March 2020: https://plsqld. com/wp-content/uploads/2020/03/COVID-19-Statement.pdf.

Condry R., Minson S., "Conceptualizing the effects of imprisonment on families: Collateral consequences, secondary punishment, or symbiotic harms?", Theoretical Criminology 2020:1-19. Doi.org/10.1177/1362480619897078.

Cranmer, L., Goff, M., Peterson, B., Sandstrom, H., Parent-Child visiting practices in prisons and Jails: A Synthesis of Research and Practice Research Report (Washington D.C: Urban Institute, 2017).

Dallaire, D., "Children with Incarcerated mothers: Developmental outcomes, special challenges and recommendations", Journal of Applied Developmental Psychology 2007 (28), 15-24.

Duque, M., McKnight, A., Understanding the relationship between inequalities and poverty: mechanisms associated with crime, the legal system and punitive sanctions, CASEpaper 215/LIPpaper 6 London: LSE/Joseph Rowntree Foundation (2019).

Flynn, C., "Getting there and Being there:Visits to Prisons in Victoria - the Experiences of Women Prisoners and their Children", Probation Journal 2014 (61(2)), 176-91.

Garcia, J., "Understanding the Lives of Mothers after Incarceration: Moving Beyond Socially Constructed Definitions of Motherhood", Sociology Compass 2016 (10(1)), $3^{-11 .}$

Garcia-Quiroga M., Agoglia I. S., "Too Vulnerable to Participate? Challenges for Meaningful Participation in Research With Children in Alternative Care and Adoption", International Journal of Qualitative Methods, January 2020.

Glaze, L. E. and Maruschak, L.M., Parents in prison and their minor children, Report No. NCJ 222984, Washington: US Department of Justice, Bureau of Justice Statistics (2008). 
Knudsen, E. M., "The Systemic Invisibility of Children of Prisoners", in Prisons, Punishment and the Family: Towards a New Sociology of Punishment, ,P. S. Smith, , R. Condry (eds.) (Oxford: Oxford University Press, 2018).

Leigh, A., "The Second Convict Age: Explaining the Return of Mass Imprisonment in Australia", Economic Record 2020 (96), 187-208.

Loucks, N., "Prison Without Bars: Needs, Support, and Good Practice for Work With Prisoners' Families" (Edinburgh: Families Outside, 2004).

Lundy L., McEvoy L., "Children's rights and research processes: Assisting children to (in)formed views", Childhood 2012 (19(1)), 129-144.

Mackintosh, V. H., Myers, B. J., Kennon, S. S., "Children of Incarcerated Mothers and their caregivers: factors affecting the quality of their relationship", Journal of Child and Family Studies, 2006 (15(5)), 581-196.

Mahon, A., Glendinning, C., Clarke, K. and Craig, G., "Researching Children: Methods and Ethics", Children and Society 1996 (10), 145-154.

Maruschak, L. M., Bronson, J. and Alper, M., Parents in prison and their minor children, Survey of prison inmates 2016 (2021): https://www.bjs.gov/index. cfm?ty=pbdetail\&iid=73og.

McCrickard, R., Flynn, C., Responding to children of prisoners: the views of education professionals in Victoria, Children Australia 2015 (41(1), 39-48.

Mears, D. P., Siennick, S. E., "Young Adult Outcomes and the Life-Course Penalties of Parental Incarceration", Journal of Research in Crime and Delinquency 2016 (53(1)), 3-35.

Ministry of Justice Secure, "Video calls help all prisoners maintain essential family ties during pandemic", 18 January 2021: https://www.gov.uk/government/news/ secure-video-calls-help-all-prisoners-maintain-essential-family-ties-duringpandemic\#: : text=Secure\%2ovideo\%2ocalls\%2oare\%2onow,rehabilitation\%2o during\%2othe\%2oCoronavirus\%2opandemic.

Minson, S., Maternal Sentencing and the Rights of the Child (London: Palgrave, 2019).

Moore, B., Coronavirus: Children denied contact with parents in prison, BBC News, 23 July 2020: https://www.bbc.co.uk/news/av/uk-england-oxfordshire-53498170.

Narvaez, D., Wang, L., Cheng, A., Gleason, T. R., Woodbury, R., Kurth, A. and Burke Lefever, J., "The importance of early life touch for psychosocial and moral development", Psicologia: Reflexão e Crítica/Psychology: Research and Review 2019, Springer Open. Accessed 16 September 2020: https://prc.springeropen.com/ articles/10.1186/s41155-019-0129-o.

Nesmith, A., Ruhland, E., "Children of incarcerated parents: challenges and resiliency, in their own words", Children and Youth Services Review 2008 (30(10)), 1119-1130. Doi.org/10.1016/j.childyouth.2008.02.0o6.

Office for National Statistics, 2020, Average Household Income, UK. Financial Year ending 2020 (provisional): https://www.ons.gov.uk/peoplepopulationandcommunity/ 
personalandhouseholdfinances/incomeandwealth/bulletins/household disposableincomeandinequality/financialyearending2ozoprovisional\#: : text=Main\%2opoints,2019\%2C\%2oafter\%2oaccounting\%2ofor\%2oinflation.

Prison Reform International, Global Prison Trends, 2020: https://cdn.penalreform. org/wp-content/uploads/2020/o5/Global-Prison-Trends-2020-Penal-ReformInternational-Second-Edition.pdf. Accessed 2o September 2020.

Richie, B. E., "Challenges Incarcerated Women Face as they return to their communities: findings from life history interviews", Crime \& Delinquency 2001 (47(3)), 368-389.

Scharff Smith, P. and Jakobsen, J., "Visiting in prisons: Staff, children, conditions and practice", in P. Scharff Smith (ed.), When the Innocent are Punished: The Children of Imprisoned Parents [E-Book], (Palgrave Macmillan, New York, 2014), 144-16o.

Tasca, M., "The (Dis)continuity of parenthood among incarcerated fathers: An analysis of caregivers' accounts", Child Care in Practice 2018 (24(2), 131-147.

Tasca, M., Wright, K., Turanovic, J., White, C., Rodriguez, N. “Moving Visitation Research Forward: The Arizona Prison Visitation Project” Criminology, Criminal Justice, Law and Society (2016) 17(1):55-67.

Tashakkori, A. and Teddlie, C., Handbook of mixed methods in social and behavioural research (2nd ed.) (SAGE Publications, Ltd, US, 2010).

Trotter, C., Flynn, C., Naylor, B., Collier, P., Baker, D., McCauley, K. and Eriksson, A., The impact of incarceration on children's care: A strategic framework for good care planning (Monash University, Melbourne, 2015).

United Nations Committee on the Rights of the Child General Comment No.12, The United Nations Convention on the Rights of the Child (Geneva: United Nations, 2009). van de Weijer, S. G. A., Smallbone, H. S. and Bouwman, V.J. Dev., "Parental Imprisonment and premature mortality in adulthood "Journal of Life Course Criminology (2018), $1-14$.

Wakefield, S., Wildeman, C., Children of the prison boom: Mass incarceration and the future of American inequality (Oxford: Oxford University Press, 2014).

Western, B., Pettit, B., "Incarceration and social inequality" Daedalus 2010 (139(3)), 8-9. World Health Organization, "Preventing CoviD-19 outbreak in prisons: a challenging but essential task for authorities" (2020). Accessed 19 September 2020: https://www. euro.who.int/en/health-topics/health-emergencies/pages/news/news/2020/03/ preventing-covid-19-outbreak-in-prisons-a-challenging-but-essential-task-forauthorities.

Williams, K., "Daddy gone now': Anguish of women who say their kids have lost interest in their jailed dads because they can't visit them in the pandemic", Manchester Evening News, 14 February 2021: https://www.manchestereveningnews.co.uk/news/ greater-manchester-news/daddy-gone-now-anguish-women-19710287. 


\section{Case Law}

$R$ (on the application of $P$ and $Q) v$ Secretary of State for the Home Department [2001] EWCA Civ. 1151.

Conventions

United Nations Convention on the Rights of the Child, 1989.

\section{Statutes}

Australia

Charter for Human Rights and Responsibilities Act 2006.

Human Rights Act 2004 (ACT).

Human Rights Act 2019 (Queensland).

England and Wales

Human Rights Act 1998. 